\title{
BASILEK SEBAGAI REPRESENTASI KEKUASAAN DAN KEAKRABAN DALAM TUTUR PENOLAKAN PADA INTERAKSI JUAL-BELI PASAR TRADISIONAL
}

\author{
Meydita Chrysan ${ }^{1 *}$, Gigit Mujianto ${ }^{2 *}$ \\ 1, 2 Prodi Pendidikan Bahasa dan Sastra Indonesia \\ Fakultas Keguruan dan Ilmu Pendidikan \\ Universitas Muhammadiyah Malang \\ 1ditachysn13058@gmail.com, ${ }^{2}$ gigitmujianto@gmail.com
}

\begin{abstract}
ABSTRAK
Penelitian ini bertujuan untuk memberikan pemahaman wujud pola model Brown-Gilman pada bentuk kekuasaan (power) dalam berkomunikasi berdasrakan faktor vertikal(Status Sosial) keakraban (solidarity) dalam berkomunikasi dari segi horizontal dan bentuk tutur penolakan dalam interaksi jual-beli di pasar tradisional. Metode yang digunakan kualitatif berupa ujaran lisan serta interaksi yang terjalin dalam proses jual-beli berupa kalimat maupun . Sumber data dalam penelitian ini terkait dengan penggunanaan variasi bahasa basilek berdasarakan perbedaan status sosial, keakraban yang mempengaruhi tutur penolakan dalam interaksi jual-beli. Sumber data penilitian ini berasal dari berbagai temuan sumber dan data dalam situasi interaksi jual-beli di pasar tradisional. Pemerolehan data penelitian ini menggunakan teknik observasi dan studi pustaka. Hasil penelitian ini mampu dipahami (1) Bahasa Basilek dalam Komunikasi Prespektif Model Brown dan Gilman diklasifikasikan beradasarkan kekuasaan dan keakraban untuk mempengaruhi mintra tutur 2). Pola Tutur Penolakan dalam Interaksi JualBeli menghasilkan pengaruh negatif dengan memperhatikan norma tutur.
\end{abstract}

Kata Kunci : Basilek, Kekuakasaan, Keakraban, Interaksi Jual Beli, Penolakan

\begin{abstract}
This study aims to provide an understanding of the Brown-Gilman model pattern in the form of power in communication based on vertical factor social status familiarity (solidarity) in communcating horizontally and the form of speech rejection in the interactioan of buying and selling in tradisional markets. The appoarch used is qualitative. The data in this study are relate to the use of basilek languange variation based on differences in social status, familitarity that affect speech disclaimers in buying and selling interaction. This reserach data source comes from a variety of source and data finding in situation of buying and selling interaction in tradisiomal market. Obtaining this research data using obervastion and literature study. The result of this study can be understood (1) Basilek languanges in the prespetive communication Brown dan Gilman are classified based on power and familiarty to influence speech, 2) Rejection speech patterns in sale-purchas interaction produces a negative effect by paying attention to speech norms.
\end{abstract}

Keyword : Basilek, Power,Familiarity, Sale and Purchase Interaction, Rejecton

\section{A. PENDAHULUAN}

Bahasa merupakan media dalam berinteraksi antara individu dengan individu atau individu dengan kelompok. Sebagai makhluk sosial yang saling berinteraksi, maka manusia membutuhkan bahasa untuk dapat menyampaikan pikiran, gagasan, dan sebagainya. Bahasa merupakan sistem lambang bunyi yang bersifat mana suka dan digunakan oleh seseorang untuk melakukan interaksi dengan orang lain yang berada di lingkungannya. Selain digunakan untuk berinteraksi, bahasa juga dapat 
digunakan dalam berkomunikasi antar manusia, dalam arti bahasa digunakan sebagai alat untuk menyampaikan pikiran, gagasan, konsep, atau pun perasaan dalam (Chaer, 2010:15). Faktor-faktor sosial yang mempengaruhi pemakaian bahasa, misalnya status sosial, tingkat pendidikan, umur, tingkat ekonomi, jenis kelamin, dan sebagainya dalam tindak tutur.

Tindak tutur juga dapat dikatakan sebagai bagian dari aktivitas verbal dalam suatu peristiwa tutur. Peristiwa tutur, situasi tutur, dan tindak tutur merupakan bentuk nyata dari kegiatan bertutur dalam masyarakat tutur, baik antaranggota, antarkelompok, dalam penelitian ini menitik beratkan pada masyarakat penutur dengan latar belakang ekonomi pedangan dan sebagai penerima tutur yang berbeda status sosial. Sehingga perbedaan karakteristik inilah yang menghasilkan variasi berbeda-beda berdasakan makna yang akan disampaikan.

Dewasa ini proses komunikasi sosial merupakan penerapan dari ilmu sosiolonguistik. Sosiolonguistik sendiri merupakan perpaduan dari ilmu sosial dan linguistik. Ilmu ini menelaah bagaimana penggunaan bahasa pada proses berkomunikasi masyarkat menurut beberapa kaidah kebahasaan. Setiap bahasa yang digunakan masyarkat memiliki berbagai macam bentuk penyampaian baik dari segi fonetik hingga morfem disebut sebagai variasi bahasa.

Faktor berbagai macam munculnya variasi bahasa yaitu, proses penutur menyampaikan sebuah tujuan atau pesan dan proses memahami pesan dari penutur. Hal tersebut menunjukan peran bahasa mampu menciptakan berbagai macam situasi tutur berdasarkan latar belakang penutur dengan penerima. Adapula berbagai macam variasi bahasa antara lain akrolek, jargon, register dan fungsiolek. Sedangkan penelitian dalam makalah ini berfokus pada penggunaan variasi basilek.

Variasi yang sering digunakan dalam proses interaksi jual beli di pasar tradisional adalah Basilek sendiri merupakan bentuk tutur variasi bahasa yang dianggap kurang bergengsi atau bahkan dianggap lebih rendah. Bahasa yang dianggap lebih rendah merupakan bahasa sehari-hari yang digunakan dalam suatu situasi berkomunikasi tertentu. Bahasa dalam hal ini menginterpretasikan pengguna bahasa itu sendiri yang berada pada kalangan menengah kebawah misalnya pada pedagangan dan buruh dalam (Ibrahim,2009:75).

Variasi basilek mampu dijabarkan dalam penelitian dalam interkasi jual- beli antara pedangan dengan pembeli yang memiliki faktor sosial tertentu. Proses interaksi jual beli antara pedagang dan konsumen. Hal tersebut sering ditemui perbedaan latar belakang status sosial. Misalnya, pembeli sebagai salah satu pejabat terkait dengan pedagang yang cenderung berintelektual lebih rendah. Interaksi yang tercipta menggunakan bahasa yang tergolong basilek terutama pada tanah Jawa yang cenderung menggunakan Bahasa Jawa Krama. Hal ini sering ditemui di kelompok masyarakat tradisional atau faeodal yang berbasis agraris dengan latar belakang sebagai seorang petani atau pedangang. Pada proses interkasi jual- beli sering ditemui pihak-pihak tertentu yang dianggap memiliki status sosial di atas rata-rata mampu dengan mudah mengakomodir proses transaksi tersebut. 
Basilek dalam interaksi jual-beli dalam makalah menunjukkan proses komunikasi yang didasari atas pemenuhan kebutuhan. Bentuk penggunaan bahasa penolakan yang dilakukan oleh penjual dan pembeli merupakan sebuah peristiwa tutur yang terjadi di setiap masyarakat tutur di pasar tradisional. Bahasa yang digunakan di pasar tradisional sebagian besar menggunakan bahasa ibu yakni Bahasa Jawa Krama. Pemakaian bahasa tersebut menunjukkan perbedaan status sosial yang berkuasa dan persamaan derajat menggunakan bahasa yang dianggap lebih mudah dipahami untuk mencapai sebuah kesepakatan dalam interkasi jual beli. Proses ini sering menunjukkan pernyataan persetejuan maupun penolakan. Penolakan merupakan pernyataan kurang setuju atas sebuah keputusan atau sering disebut sebagai menolak

Menolak merupakan salah satu tindak tutur (Vanderken, dalam F.X. Nadar, 2005:166-178) sehingga dapat dipahami bahwa penolakan akan menjadi lebih mudah apabila didahului dengan pemahaman tindak tutur. Brown dan Levinson (dalam F.X. Nadar, 2005) penolakan diklasifikasikan sebagai suatu tindakan yang dapat mengancam muka negatif dan muka positif dari lawan tutur. Sehubungan dengan itu, agar penolakan dianggap sebagai penolakan yang sopan, maka dibutuhkan strategi yang harus digunakan, baik strategi positif maupun strategi negatif.

Gunarwan dalam Rosnilawati (2014) menyimpulkan bahwa terdapat empat strategi utama yang digunakan untuk mengutarakan agar muka tidak terancam dan didasarkan pada derajat ketenteramannya, diantaranya (1) bertutur secara terusterang tanpa basa-basi; (2) bertutur dengan menggunakan kesantunan positif; (3) bertutur dengan menggunakan kesantunan negatif; dan (4) bertutur secara samarsamar atau transparan; atau bertutur 'dalam hati' dalam arti penutur tidak bermaksud untuk mengucapkan maksud hatinya.

Dalam sebuah lakuan tutur penolakan, Watts dalam Hadi (2016) menguraikan panjang lebar mengenai lakuan tutur menolak (kesantunan negatif) secara gamblang ke dalam sepuluh bentuk, yaitu (1) mengungkapkan secara tidak langsung; (2) menggunakan bentuk pertanyaan dengan partikel tertentu; (3) membicarakan secara hati-hati dan tidak terlalu optimistik; (4) mengurangi kekuatan atau ancaman terhadap mitra tutur; (5) memberi penghormatan; (6) memohon maaf; (7) tidak menyebutkan penutur dan mitra tutur; (8) menyatakan lakuan mengancam wajah sebagai suatu ketentuan sosial yang umum berlaku; (9) menominalkan pernyataan; dan (10) menyatakan secara jelas bahwa penutur telah memberikan kebaikan atau tidak kepada mitra tutur.

Penelitian terkait dengan bahasa penolakan sudah pernah dilakukan dengan prespektif berbeda dalam pemerolehan bahasa dalam berkomunikasi kegiatan jual beli ini sudah pernah dilakukan. Menurut Imron Hadi dengan judul Lakuan Tutur Menolak dalam Transaksi Jual Beli: Analisis Bentuk dan Makna terhadap Penggaleh Babelok pada Pasar Tradisional di Kabupaten Solok. Hasil penelitian ini pada lakuan tutur penolakan dan bentuk-bentuk lakuan tutur penolakan dalam kegiatan jual beli 
di pasar tradisional (dalam Imron,2016:439-440). Pandangan lain penelitian yang sering dilakukan terhadap penelitian terdahulu yang dilakukan oleh Nurlina Arisnawati dengan judul Strategi Kesantunan Tindak Tutur Menolak dalam Bahasa Makassar berfokus kepada strategi kesantunan dari tindak tutur menolak yang dilakukan oleh pembeli dan para pedagang (dalam Arisnawati,2015:67-68). Hal tersebut diperkuat dengan penelitian lainnya juga. Menurut Sholihah dengan judul Analisis Sosiolinguistik Bentuk Bahasa Penolakan dalam Transaksi Jual Beli di Pasar Klewer Surakarta yang hasil penelitian membahas mengenai bentuk-bentuk bahasa penolakan yang dilakukan oleh pembeli saat bertransaksi dengan pedagang di pasar tradisional Klewer(dalam Sholiha,2013:98-100).

Fokus penelitian ini bertujuan untuk memberikan pemahaman wujud pola model Brown-Gilman pada bentuk kekuasaan (power) dalam berkomunikasi berdasrakan faktor vertikal(Status Sosial) keakraban (solidarity) dalam berkomunikasi dari segi horizontal dan bentuk tutur penolakan dalam interaksi jual-beli di pasar tradisional. Penilitian ini memiliki tingkat urgensi dengan sosiolonguistik dengan memberikan pemahaman lebih proses komunikasi dimasyarakat berdasarakan status soial dan menunjukkan dampak dari bahasa penolakan dalam interaksi jual-beli pada pasar tradisional.

\section{B. METODE PENELITIAN}

Penelitian ini menggunakan jenis penelitian kualitatif dengan pendekatan menggunakan deskriptif. Menurut Jauhari menjelaskan, "metode deskriptif merupakan metode yang memberikan gambaran atau secara deskriptif mengenai objek sehingga dapat diperoleh informasi tentang kondisi subjek atau objek penelitian." Pendapat Jauhari dapat ditarik sebuah kesimpulan bahwa metode deskriptif mengilustrasikan relevansi kondisi sebuah sumber data penelitian secara akurat dengan tujuan untuk menguak sumber data dan atau objek penelitian secara lebih detail (dalam penelitian Fatmawati dkk, 2017: 421).

Pendekatan deskriptif menggambarkan fakta-fakta yang ada pada objek penelitian. Pendapat tersebut selaras dengan beberapa pendapat ahli Bodgan dan Guba (dalam Andalas ,2018:4) menjabarkan bahwa penelitian kualitatif ialah penelitian yang bertujuan menitik beratkan pemahaman peristiwa yang terdapat dalam sumber data penelitian, baik seperti konflik, perspepsi, perilaku, tindakan, dan segala bentuk aktivitas dalam suatu objek penelitian secara holistik dengan cara mendeskripsi dalam penjelasana bentuk kosakata dan bahasa. Metode deskriptif untuk melakukan analisis data dengan cakupan berupa frasa Mileong (dalam (Prihatini, Andalas, 2018:4).

Objek instrumen yang digunakan melakukan penilitian bahasa pada interaksi jual-beli pada pasar tradisional. Data yang diperoleh secara akurat dan valid dapat dipertanggung jawabkan. Teori yang digunakan dalam penelitian ini merupakan Teori Model Brown dan Gilman yang terfokus pada proses komunikasi yang menggunakan bahasa tertentu dari segi kekuasaan (power) dan keakraban 
(solidarity) dengan mengkaji variasi bahasa Basilek yang ada dalam lingkungkan sekitar. Subjek pendukung selain dari peniliti juga ditunjang dengan beberapa sumber baik jurnal maupun buku sesuai dengan topik penelitian.

Penggunaan teknik penelitian tersebut diharapkan mampu mampu memberikan data yang akurat sesuai dengan kondisi dilapangan yang benar-benar terjadi. Teknik analisis data digunakan metode deskriptif-analitik. Pada setiap data yang telah dikemas kemudian diuraikan dengan mengaitkan dengan teori yang digunakan dalam penelitian. Untuk menunjang proses penelitian ini digunakan jurnal-jurnal sebagai acuan penelitian.

\section{HASIL}

Komunikasi dengan media bahasa dalam tindak tutur ditinjau dari segi variasi bahasa basilek perwujudan bentuk status sosial menghasilkan tutur penolakan dalam interaksi jual-beli di pasar tradisional sebagai upaya pemahaman perbedaan status sosial dalam penggunaan bahasa tutur. Interaksi jual-beli menunjukkan pemilihan bahasa secara tepat sesuai dengan penutur dan lawan penutur.

\section{Bahasa Basilek dalam Komunikasi Prespektif Model Brown dan Gilman}

Bahasa basilek dalam komunikasi sebagai wujud model Brown dan Gilman memiliki dua prespektif dalam tindak tuturnya yaitu kekuasaan (power) secara vertikal dan keakraban (solidarity) secara horizontal sesuai dengan latar lingkungan dalam proses komunikasi.

\subsection{Kekuasaan (Power) Secara Vertikal}

Bentuk tuturan yang terdiri dari frasa, klausa, maupun kalimat yang digunakan untuk menyatakan dengan mengedepankan sisi status sosial yang mempengaruhi sebuah komunikasi. Bentuk tuturan ini menunjukkan status sosial berkenan dengan posisi atau kedudukan seseorang dalam sebuah tatanan masyarkat baik dari segi intelektual maupun kekuasaan seseorang. Hal tersebut tampak pada sumber data di bawah ini.
Akses utawa dampak saka larangan BI dhuwur panggunan mata dhuwit virtual bitcoin iki akeh disimak saka pamaca kanal ekonomi.Kompas kabar sing uga disimak yaiku masalah kelangkaan gas elpiji 3 kilogram (subsidi) utawa gas melon. Adoh-adoh dina, neng awal 2017, Presiden Joko Widodo (Jokowi) wis ngendikakake yen penyaluran gas Elpiji 3 kilogram (subsidi) wis salah sasaran.

Bahasa dalam komunikasi tersebut menunjukkan variasi bahasa basilek yang digunakan dalam proses tuturan. Pada sumber data yang diperoleh menunjukkan sebuah interaksi melalui berita disalah satu surat media sosial online dengan menggunakan Bahasa Jawa. Mampu dipahami berdasarkan sumber data tersebut komunikasi menghasilkan dominasi kekuasaan atau status sosial seseorang dalam menyampaikan 
argumen yang sudah menjadi keputusan mutlak dalam menentukan harga gas tabung elpiji.

Dalam sumber data dijelaskan penutur ialah bapak Presiden Republik Indonesia Joko Widodo beliau yang memiliki kekuasaan tertinggi mengintruksikan agar penyaluran subsidi tepat sasaran. Hal tersebut merupakan bentuk interaski yang berasaskan kekuasaan seseorang untuk mempersuasif orang lain dalam menjalankan apa yang telah ditetapkan.

\section{Menteri Keuangan Sri Mulyani Indrawati ngarep-arep masyarakat ora nglakoke spekulasi kanthi investasi neng dhuwit virtual, sak-werna bitcoin. \\ “ Kanggo Indonesia sing nampake kerep dimunculke amarga regane dhuwur, iki dilirik dadi mubarang bentuk investasi. Nangging kami ora ngarep-ngarep kedaden spekulasi utawa investasi sing banjur bisa manake" ujar Mulyani, neng Jakarta, Kamis (7/12/2017)}

Proses komunikasi yang mengacu pada kekuasaan dalam data di atas menunjukkan peran status sosial merupakan landasan utama dalam proses berkomunikasi yang akan menjadi kekuatan tersendiri dalam mempengaruhi pembaca atau pendegar. Informasi yang disajikan menyangkut para petinggi atau pejabat terkait yang mempunyai kekuasaan dalam pengelolaan ekonomi. Informasi yang disampaikan ibu Sri Mulyani selaku Menteri Keuangan inilah menunjukkan status sosial berupa kekuasa menentukan proses berkomunikasi. Tampak bahasa yang digunakan juga lebih bervariasi sesuai topik bahasan untuk mempersuasif pendegar. Meskipun dalam penyampaiannya terkesan tidak kaku. Namun, bahasa dan tujuan yang disampaikan lebih terarah dan dianggap terpercaya berlandaskan latar belakang penutur.

Saka pawarta iki Menteri Perdagangan ngaturake bakalan ono operasi pasar murah amarga paceklik kang ngurngikake wong dodolan lan konsumen. Kuwi bakal dadi trasformasi kangge ngendaliake harga bahan pangan supaya dene terjamin.

\section{“ Kulo bakal nindaklanjuti rego-rego kang awit ing masyarakat sakderengge tahun baru 2020. Inflasi kae bakal dimuduk ake saka subsidi beras lan lianne"}

Proses penyampaian informasi berdasarkan sumber data proses komunikasi di atas merupakan penggalan dari salah satu berita dalam salah satu surat kabar online. Dalam sumber data tersebut disampaikan oleh salah seorang pejabat terkait dalam bidang perdagang yaitu Menteri Perdagangan. Proses interaksi tersebut dalam wawancara sidak penanganan operasi pasar atas harga bahan kebutuhan pokok. 
Berdasarkan ujaran beliau mampu mempersuasif pendengar akan tindakan tegas yang dilakukan agar tidak merugikan antara pedagang dan pembeli. Status sosial dalam hal ini sangat dominan karena tindakan turun tangan langsung oleh kekuasaan sesorang. Sehingga dalam proses interaksi mampu memberikan pemahaman tersendiri oleh pendegar atas pesan dalam komunikasi yang ingin disampaikan.

\subsection{Keakraban (Solidarity) dalam Interaksi Jual-Beli}

Proses interaksi melibatkan antara penutur dan penerima tuturan berupa informasi yang hendak disampaikan dengan tujuan tertentu. Bentuk interaksi sendiri dalam masyarakat mempunyai berbagai macam variasi termasuk dengan latar ekonomi. Interaksi yang terjalin dalam jual-beli sering ditemui bahwasannya menggunakan prinsip keakraban atau kesamaan derajat dalam mencapai sebuat kesepakatan jual-beli. Hal tersebut menunjukkan hubungan kesamaan derajat berkaitan dengan keakraban yang terbentuk dalam sebuah latar sosial atas dasar latar keluarga maupun kesamaan.

\section{Percakapan PB : (01) “de' gaga kah lipa' bate' samarenda ta balu bu?"}

"(apakah tidak ada sarung samarenda yang kita jual?)"

PJ : (02) "engka-engka tamani' mai,?" "(ada masuk )

PB : (03) "cora laing nge"

"(jenis yang lain)

" PJ : (04) “denggka ni , cappu'ni. Pakkutunggi mani

(tidak ada lagi, sudah habis yang tersiasa tinggal itu)"

PB : (05) "oh..wasenggi engka mompi, jokka-jokk pale yolo".

"(saya kira masih ada, saya jalan- jalan dulu)"

Interaksi jual-beli di atas menunjukkan bahwa tampak proses interaksi antara penjual dan pembeli dalam menentukan pilihan membeli sebuah barang. Interaksi tersebut mengunakan latar Bahasa Bugis memiliki ragam berupa Bahass Bugis Pare-Pare dan Donggala yang sebagian kalangan adat saja memahmi betul makna dalam setiap kosa kata. Penutur pun sebagian besar orang menengah kebawah yang ditijau dari faktor ekonomi. Dalam segi bahasa pemilihan kosa kata juga tampak lebih terkesan akrab dan tidak kaku. Hal ini menunjukkan kesamaan derajat antara pembeli dan penjual yang saling membutuhkan menghasilkan simbiosis dalam memenuhi sebuah kebutuhan khususnya keberhasilan interkasi.

Konteks I: pembeli dari etnis Cina

Pembeli : "Berapa apel sekilo, Ci?"

Pedagang : "Lima ble ribu sekilonya".

Pembeli : "Beli dua kilo. Ada jaul

susu, Ci?" 


\section{Pedagang : "Ya, ambil saja lah. Nanti \\ saya timbang."}

"Susu apa ha? Sincai atau

lebih?"

Pembeli : "Susu Dancaow. Satu

yang berat $500 \mathrm{gr} . "$

Interaksi jual-beli di atas merupakan proses interaksi yang menunjukkan hubunggan persamaan suku terjalin dalam proses komunikasi sehingga menghasilkan sebuah kesepakatan. dalam percakapan kedua menunjukkan latar sosial yang dipengatuhi oleh kelompok masyarakat etnis tertentu yang bertempat tinggal sejak lama dikawasan tersebut. Status sosial seorang pedagang dan pembeli beretnis Cina.

Keakraban itu sudah mulai tampak dalam proses interaksi jualbeli tersebut dalam rumpun etnis yang sama. Latar sosial menunjukkan ikatan keluarga dalam etnis dengan tetap mengedepankan penghormataan satun dalam proses jual-beli. Interkasi tersebut semakin kental akan keakraban dengan penggunaan bahasa daerah Minangkabau tidak lepas dengan logat tionghoa seperti dalam kalimat 'Lima bleribu' yang bermakna Lima belas ribu sekilo dengan dibubuhi tuturan sincai dalam bahasa Tionghoa menunjukkan jumlah. Hal tersebut merupakan bentuk interaksi yang berdasarakan persamaan etnis dalam penyampaianya menggunakan bahasa yang mudah dipahami antara pedagangan dan pembeli.

PJ 1 : Kie wis kukumpul durung?

(Ini sudah kumpul-kumpul belum?)

(PM 2) : Nya nawarna teu nanaon, nya sok lima rebu.

(Ya, menawarkannya tidak apa. Ya, silakan lima ribu).

(PJ 1) : Ari ngical mah dua belas, pedah bae ka Bu Haji.

(Kalau menjual sih dua belas, ini karena dengan Bu Haji).

(PM 2) : Embung, geneup, eta ngomong tujuh.

(Tidak mau, enam, katanya tujuh).

(PJ 1) : Ayeuna mah nuju usum make lepis.

(Sekarang sedang musim memkai levis)

PM 2 : Dua dua bae tah jeung ngalariskeun keur urang. Urang dua rebu, ngajual mah dua lima bae.

Dua-dua saja tuh supaya laku saja, untung dua ribu untuk saya, menjualnyadua lima saja).

(PJ 1) : Tilu opat ti dituna, ayeuna naek sapuluh teu ngabobodo.

(Tiga empat dari sananya, sekarang benar-benar naik menjadi sepuluh)

Pada proses interaksi jual-beli menunjukkan komunikasi yang dilatar belakangi oleh keakraban berupa hubunggan darah dalam suatu suku tertentu akan mempermudah jalannya proses kesepakatan yang 
terbentuk. merupakan proses interaksi jual-beli yang terjadi di salah satu pasar tradisional Kota Cirebon Penutur menggunakan Bahasa Sunda dalam proses komunikasi merupakan bentuk penunjuk dari latar sosial keakraban antara masyarakat sunda.

Dalam interaksi jual-beli yang terbentuk mengarah dalam persetujuan untuk membeli jumlah barang dengan harga murah tampak dalam kalimat, Dua dua bae tah jeung ngalariskeun keur urang. Urang dua rebu, ngajualmah dua lima bae.

Kalimat tersebut bermakna bahwa antara pedagang dan pembeli yang akan menjual kembali barangnya harus imbang dengan keuntungan sepadan dikarenakan pembeli telah lama menjadi konsumen dari penjual. Hubunggan interaksi jual-beli terbemtuk selain dari sisi persamaan status masyarkat adapula faktor keakraban yang terbentuk dari insensitas rutin dalam berkomunikasi. Latar bahasa sangat erat kaitannya dengan ragam bahasa yang berada dalam kalangan feodal tertentu saja yang mudah memahami komunikasi tersebut.

Penjual 1: Panjengengan kersa sing endi?

Anda mau yang mana?

Pembeli: Aku golek sing sepasang, ana pora?

Aku cari yang sepasang, ada tidak?

Penjual 2: Nak sepasang aku gawa ki.

Kalau sepasang saya bawa ini.

Penjual 1: Aku yo ana, tapi sing siji ning omah. Aku juga ada, tapi

yang satu di rumah.

Interkasi jual-beli di atas menunjukkan bahwasannya Tindak tutur dalam sumber data keempat tersebut menjelaskan proses interaksi yang terbentuk dalam jual-beli di pasar tradisional. Proses interaksi jual beli berupa penawaran akan kebutuhan yang diperlukan oleh konsumen dengan pedekatan bahasa Jawa Krama. Penawaran yang terjadi dengan menunjukkan beberapa pilihan yang dianjurkan oleh pedangang atas keinginan pembeli. Hal tersebut merupakan dasar keakraban yang terjalin agar antara pedagang dan pembeli lebih objektif dalam menilai sebuah barang. Pendekatan keakraban berdasarkan status sosial sama akan menghasilkan sebuah proses interaksi tercapai dengan baik. Sehingga pembeli akan merasa disegani oleh penjual untuk memutuskan pilihan jual-beli tersebut.

\section{Pola Tutur Penolakan dalam Interaksi Jual-Beli}

Tuturan verbal yang diucapkan sesorang atas ketidaksetujuan sebuah keputusan yang diambil dari salah satu pihak menunjukkan sebuah hasil 
komunikasi yang menghasilkan penolakan atas beberapa pertimbangan setelah terjadinya diskusi.

Tutur penolakan sendiri akan menghasilkan berbagai macam pengaruh terbagi menjadi dua, dampak positif dan dampak negatif. Dampak positif berasal dari kata dampak dan positif. Dampak yang berarti pengaruh atau keinginan untuk membujuk seseorang untuk mendukung tujuan kita, sedangkan kata positif dapat dikatakan sebagai pernyataan yang pasti atau tegas dari suatu pikiran terutama hal-hal yang baik. Jadi, dampak positif adalah keinginan untuk mempengaruhi orang lain dengan tujuan agar mereka mengikuti hal-hal yang baik.

$\begin{array}{cl}\text { Pembeli } & \begin{array}{l}\text { : Mbakone pintenan buk? } \\ \text { (Tembakaunya berapa buk) }\end{array} \\ \text { Penjual } & \begin{array}{l}\text { :Sekawan Ewu mbak } \\ \text { (Empat ribu mbak) }\end{array} \\ \text { Pembeli } \quad \text { :Tigang ewu buk, mboten angsal buk? } & \text { (Tiga ribu buk, tiga ribu tidak boleh) } \\ \text { Penjual } \quad \text { : Ngaturaken lepat mbak, nek niki malah angsal tigo } \\ \text { setengah mbak }\end{array}$

(Mohon maaf mbak, kalau ini bolehnya tiga ribu limaratus mbak)

Pembeli : O, nggeh mpun

$(0$, ya sudah)

Bentuk tutur penolakan dalam interaksi jual-beli di atas menunjukkan Tindak tutur dalam sumber data menunjukkan sebuah komunikasi mengambarkan suasana keakraban sangat kental dalam pengunaan interaksi yang menghasilkan penolakan antara pembeli dan penjual. Mampu dipahami bahwa, proses interaksi jual beli yang dilaksankan di pasar tradisional untuk membeli tembakau dengan menawarnya. Harga yang diujarkan merupakan ketentuan yang diperoleh sesuai beberapa aspek dalam penjualan. Sehingga adanya penawaran timbul karena proses komunikasi berlandaskan faktor ekonomi kemampuan pembeli untuk memperoleh suatu barang. Sesuai dengan sumber data yang diperoleh proses berkomunikasi instrumen yang digunakan ialah Bahasa Jawa Krama.

Bahasa Jawa Krama merupakan salah satu bentuk variasi bahasa basilek yang dianggap lebih rendah dari bahasa lainnya. Tampak dalam tuturan Ngaturaken lepat mbak, nek niki malah angsal tigo setengah mbak. Dominasi penolakan dalam sumber menunjukkan penolakan tuturkan oleh penjual secara sopan dan halus dengan menghaturkan permintaan maaf terlebih dahulu. Secara implisit penyampaian penolakan menunjukkan strategi positif yaikni, bertutur dengan menggunakan kesantunan positif.

Pembeli:Sampeyan nguculake pinten?

Anda melepaskan berapa?

Penjual: Wis tak omong, tak uculke telung ewu. 
Sudahku bilang, aku lepaskan tiga ribu (tiga juta).

Pembeli: Mbok dikurangi, nem likur ngono yo.

Tolong dikurangi, dua puluh enam (dua puluh enam juta) ya.

Penjual: Ora isa. Wis pas semono. Tidak bisa. Sudah pas segitu.

Bentuk tutur penolakan di atas menunjukkan bahwa Penggalan proses interaksi -jual beli dalam sumber data kedua yakni, secara implitis dominasi variasi bahasa Jawa Krama menunjukkan latar komunikasi tersebut yang terjadi di pasar tradisional. Interaksi tersebut bentuk interaksi penolakan dari pembeli atas keputusan yang diambil penjual dalam menentukan harga sebuah barang.

Sikap dan kesopanan bahasa yang termasuk bahasa basilek yang sering digunakan oleh kalangan menenggah kebawah merupakan sisi lain dari kesantunan meskipun dalam penolakan yang terjadi dalam sumber data termasuk penolakan negatif. Penolakan negatif dilontarkan oleh sang penjual tampak dalam kalimat sebagaian berikut, Penjual: Ora isa. Wis pas semono. Tidak bisa. Sudah pas segitu. Pernyataan tersebut menunjukkan bahwa sudah tidak bisa ditawar kembali atas harga yang telah ditetapkan. Sehingga setiap penolakan yang dihasilkan mampu diterima dengan baik atas cara penyampaianya dengan memberikan alasan yang kuat atas kesamaan derajat kebutuhan sosial.

\section{PEMBAHASAN}

Penelitian ini merupakan gudang pengetahuan sebagai salah satu penerapan bahasa dalam masyarakat dengan menitik beratkan pada variasi bahasa yang bervariasi dengan mempertimbangkan status sosial dalam interaksi-jual beli yang pada kenyataanya sering menghasilkan sebuah keputusan berupa penolakan yang terbentuk. Varisi bahasa menunjukkan bentuk titik fundamental dalam pengembangan bahasa dalam masyarakat tertentu.

\section{Bahasa Basilek dalam Komunikasi Prespektif Model Brown dan Gilman}

Penggunaan bahasa wujud dari media komunikasi yang terbentuk dalam penyampaian informasi itu sendiri. Bahasa memiliki cakupan luas dalam penyampaiannya termasuk dalam variasi bahasa yang ada dalam suatu tatanan masyarakat tertentu. Variasi bahasa dalam penelitian ini menfokuskan pada variasi bahasa basilek yang sering kali digunakan oleh kalangan masyarakat menengah bawah atas latar ekonomoni tertentu.

Labov menjelaskan dalam (Ibrahim, 2009: 14-15) sikap anggota masyarakat kota dengan menerangkan prasangka berbahasa yang cenderung stabil. Hal ini terkait dengan variasi bahasa berkenaan dengan tingkat status, golongan, dan kelas sosial penuturnya berupa akrolek, basilek, vulgar, slang, kolokial, jargon. Penelitian ini mengkaji salah satu variasi tutur yaitu Basilek. Basilek sendiri merupakan bentuk tutur variasi bahasa yang dianggap kurang bergengsi atau bahkan dianggap lebih rendah. Bahasa yang dianggap lebih 
rendah merupakan bahasa sehari-hari yang digunakan dalam suatu situasi berkomunikasi tertentu. Bahasa dalam hal ini menginterpretasikan pengguna bahasa itu sendiri yang berada pada kalangan menengah kebawah misalnya pada pedagangan dan buruh.

Dewasa ini proses komunikasi yang tergolong menggunakan variasi basilek bukan hanya ditemui dalam kehidupan sehari-hari saja. Namun, apilikasi dari penggunaan variasi bahasa ini merupakan bentuk upaya menjaga kearifan lokal dari segi bahasa. Hal tersebut diperkuat setiap daerah memiliki bahasa daerah masing-masing. Bahasa tersebut termasuk dalam bahasa basilek dikarenakan secara umum hanya mampu dipahami oleh pihak tertentu saja dengan pertimbangan baik faktor sosial maupun ekonomi.

Faktor sosial dan ekonomi inilah yang menjadi jikal bakal munculnya teori Model Brown dan Gilman. Berbagai sumber telah menjelaskan bahwa kekuasan-keakraban dipakai oleh Brown dan Gilman untuk mengkaji sistem kata ganti kedua dalam sekelompok bahasa di Eropa. Brown dan Gilman menemukan dua jenis hubungan yang melatarbelakangi penggunaan kedua kata ganti tersebut. Klasifikasi berdasarkan model ini sebagian berikut.

a. Kekuasaan (Power) secara vertikal

Kekuasaan (Power) yakni, berkaitan dengan status vertikal berdasarkan kemampuan seorang penutur yang mampu mempersuasif lawan bicara.Bahasa lebih kaku atau formal. Hal ini sering terjadi di masyarakat tardisional atau feodal agraris yang memiliki pemahaman intelektual khususnya bahasa yang masih minim.

Pihak dalam berkomunikasi yang dianggap memiliki status sosial di atas rata-rata akan lebih mudah untuk mempersuasif lawan bicara. Dikarenakan beliau yang memiki status sosial tinggi dianggap memilki intelektual yang selaras juga. Sehingga sering ditemui penghormatan tertentu dalam penggunaan bahasa.

b. Keakraban (Solidarity)

Faktor keakraban/solidaritas membicarakan persamaanpersamaan yang ada di antara mereka (Saifudin, 2006: 14). Keakraban dalam sebuah proses komunikasi menunjukkan sebuah interaksi yang terjadi dalam sebuah intensitas komunikasi yang acap kali dilakukan. Keakraban terbentuk dalam suatu komunikasi pada dasarnya menunjukkan persamaan dalam suatu suku, etnik atau ras tertentu sehingga memiliki kedekatan baik secara emosional maupun secara garis keturunan. Hal tersebut menunjukkan sebuah bentuk hubunggan emosional positif yang memberikan sebuah dampak saling memahami dan memberikan dorongan. Mampu dipengaruhi lama waktu dalam sebuah interaksi, bentuk dorongan, sehingga akan menghasilkan sebuah keterbukaan diri dalam pernyataan sebuah wujud membenarkanya. 
Penelitian ini merujuk dari hasil analisis yang telah dilakukan dalam penggunaan variasi bahasa basilek dalam proses komunikasi sebagai bentuk penerapan model Brown dan Gilman menunjukkan tingkat penggunaan bahasa berdasarakan lingkungan tertentu dalam masyarakat yang bervariasi dan masih kompleks dengan pertimbangan status sosial dan hubunggan kesamaan derajat.

\section{Pola Tutur Penolakan dalam Interaksi Jual-Beli}

Interaksi ialah sebuah hubunggan timbal balik yang didasari sebuah bentuk komunikasi antara individu dengan individu lain maupun kelompok. Interaksi akan mencapai sebuah tujuan tertentu yang tercapai apabila transparan dan jelas. Penelitian ini menunjukkan sebuah proses interaksi antara penjual dan pembeli dalam lingkup pasar tradisional. Interaksi jual-beli melibatkan antara penjual dan pembeli yang menggunakan tindak tutur sebuah bahasa tertentu. Tindak tutur itulah yang nantinya akan mengukur sebuah proses jual beli terjalin baik atau tidak.

Proses jual beli sendiri dalam Hadi (2016:442) merupakan dinamika berkomunikasi untuk mencapai sebuah kesepakatan antara konsumen dan penjual. Kesepakatan dalam hal ini berupa barang kebutuhan yang diinginkan dengan ketentuan yang disampaikan penjual berdasarkan berbagai macam aspek yang dipertimbangkan. Pasar tradisional sendiri merupakan pembelajaran awal dalam proses jual beli melalui sebuah tindak tutur antara penjual dan pembeli.

Tindak tutur adalah sebuah bentuk komunikasi secara verbal untuk menyampaikan sebuah tujuan tertentu. Menolak merupakan salah satu tindak tutur (Vanderken, dalam F.X. Nadar, 2005:166-178) sehingga dapat dipahami bahwa penolakan akan menjadi lebih mudah apabila didahului dengan pemahaman tindak tutur. Brown (dalam F.X. Nadar, 2005) penolakan.

Menolak merupakan salah satu tindak tutur (Vanderken, dalam F.X. Nadar, 2005:166-178) sehingga dapat dipahami bahwa penolakan akan menjadi lebih mudah apabila didahului dengan pemahaman tindak tutur. Brown dan bahwa kesantunan dapat dibagi menjadi dua macam,

1. Kesantunan positif dan negatif. Kesantunan positif dimaknai sebagai citra (harga diri) seseorang yang berkeinginan agar apa yang dilakukan dapat diyakini dan dihargai oleh orang lain.

2. Kesantunan negatif dimaknai sebagai kerugian atau ketergangguan akibat Face-Threatening Act (FTA).

Bentuk bahasa penolakan adalah bentuk bahasa yang digunakan dalam suasana nonformal, termasuk dalam kegiatan jual beli di pasar tradisional. Apabila dikaitkan dengan kaidah atau norma bahasa, maka bentuk bahasa penolakan adalah bentuk pemakaian bahasa yang senantiasa kurang didasarkan pada norma atau kaidah bahasa yang berlaku karena masih memiliki dampak yang kurang menyenangkan untuk mitra tutur. 
Berdasarakan klasifikasi tintak tutur penolakan sendiri antara penelitian terdahulu dan penelitian yang sedang dilakukan tampak berbeda dari berbagai unsur berikut:

\section{Mengungkapkan secara tidak langsung}

Interaksi yang dilakukan dalam proses jual beli ditemui dalam hasil penelitian dalam menyampaikan secara tidak langsung tertuju atas penolakan yang diberikan. Hal tersebut disangkal dengan penggunaan bahasa yang halus sesuai dengan norma berkomunikasi dengan orang lain. Memberi penghormatan, memohon maaf. Proses penolakan sendiri dalam penelitian ini menunjukkan bentuk penolakan dengan pengunaan bahasa yang santun tanpa menyakiti kedua belah pihak. Meskipun hasil dari diskusi menunjukkan respon negatif yang berarti menolak. Menominalkan menyatakan secara jelas

Interaksi jual-beli dalam sumber data penelitian ini banyak menghasilkan bahasa penolakan negatif dengan pernyataan penjual yang secara jelas dengan menyebutkan harga nominal yang sudah tidak bisa ditawar kembali dengan beberapa pertimbangan tertentu.

\section{E. SIMPULAN}

Penelitian ini merupakan salah satu dedikasi sebagai mahasiwa yang memperhatikan dunia pendidikan termasuk dalam perkembangan penggunaan bahasa yang berada dalam suatu masyarakat. model Brown dan Gilman yang terjadi dalam masyarakat menunjukkan bahwa faktor penentu dari komunikasi antara lain: kekuasaan (power) secara vertikal dan keakraban (solidarity) secara horizontal. Menenunjukkan penguasaan bahasa yang berlandaskan status sosial yang tinggi mampu dengan mudah mempersuasif mintra tutur yang memiliki status sosial rendah. Sedangkan dari segi keakraban sendiri menunjukkan hubunggan darah persamaan derajat terjalin karena faktor persamaan RAS,dan intensitas waktu dalam proses komunikasi. Bentuk tuturan secara verbal merujuk dalam pola interaksi yang terjalin. Interaksi yang terjalin dalam penelitian ini mengadaptasi dari interaksi jual-beli yang sering terjadi dalam pasar tradisional. Interaksi jual beli akan menghasilkan sebuah kesepakatan dalam hal ini penelitian ini ditemui penolakan interaksi jual beli.

\section{F. SARAN}

Dalam penyusunan naskah penelitian ini jauh dari kata sempurna maka kritik dan saran pada pembaca untuk sumbangsih menjadi gudang ilmu baru bahasa sangat membantu. Terkhusus pada bidang sosiolonguistik.

\section{DAFTAR PUSTAKA}

Chaer, Abdul dan Leonie Agustina. 2010. Sosiolinguistik Perkenalan Awal. Jakarta: Rineka Cipta.

Djamil,1995: Sosiologuistik, Pusat Pengembangan dan Pendidikan Bahasa

Departemen Pendidikan dan Kebudayaan, Jakarta (81-90) 
Ibrahim, Abdul Syukur 2009 : Kesemestaan Sosioluguistik, Fakultas Sastra :Univeristas Negeri Malang (9-26)

Hadi, Imron. 2016. Lakuan Tutur Menolak dalam Transaksi Jual Beli: Analisis Bentuk dan Makna terhadap Panggaleh Babelok pada Pasar Tradisional di Kabupaten Solok (The Refusal Utterances in Buying and Selling Transaction: The Analysis on Form and Meaning to Street Vendors on Traditional Markets in Solok Regency). Sawerigading, 21(3), 439-452.

Kustyarini, 2019. Simbol-Simbol Kekuasaan Lisan, LIKHITAPRAJN. Jurnal Ilmiah. Fakultas Keguruan dan Ilmu Pendidikan ISSN: 1410-8771. Volume. 18, Nomor 2 Hal 11-12

Malabar, 2015. Buku Sosiolinguistik. Ideas Publishin, Jakarta (47-50)

Maturbhong Yohanes, 2007. Variasi Bahasa, Jurnal Bahasa dan Sastra Universitas Gadjah Mada (55-67)

Sari Indah, 2007 Bentuk Sapaan Dalam Film Elizhabet Kajian Sosiologuistik, Jurnal Sastra Inggris Universitas Sam Ratulangi (13-15)

Sholihah, Ismi. 2013. Analisis Sosiolinguistik Bentuk Bahasa Penolakan dalam Transaksi Jual Beli di Pasar Klewer Surakarta. (Doctoral Dissertation, Universitas Muhammadiyah Surakarta)

Rahardi, 2005. Sosiologuistik Tataran. Jurnal Bahasa dan Sastra Vol. 4. Universitas Negeri Padang (45-47)

Rizaldi, Sumartono, 2017. Kualitas Komunikasi Keluarga dan Keakraban. Jurnal Komunikalogi Volume 14 Nomor 2 September 2017, hal 90 